\title{
Four Decades of Kidney Transplantation in Cuba
}

\author{
Jorge P. Alfonzo MD PhD
}

\section{ABSTRACT}

This article describes the background, beginnings, development, evolution and outcomes of kidney transplantation in Cuba. Nephrology as a medical specialty in Cuba began in 1962 and was formalized in 1966. Conditions were created to implement renal replacement therapy (including transplants), bring nephrology care to the entire country and train human resources who would assume this responsibility, making Cuba one of the first countries with a comprehensive program for renal patient care.

After three unsuccessful cadaveric-donor kidney transplantations in 1968-69, the ensuing history of kidney transplantation can be summarized in the following three stages. 1970-1975: In January 1970 , cadaveric-donor kidney transplantation began at the Nephrology Institute. That year, 17 kidney transplantations were performed; four of these patients lived with functional kidneys for 15-25 years; 10 -year graft survival was $23.5 \%$ (Kaplan-Meier survival curve); HLA typing began in 1974. By December 1975, 170 grafts had been done in three hospitals. 1976-1985: Seven transplantation centers per-

\section{INTRODUCTION}

Kidney dialysis and transplantation arose from the need to treat patients with end-stage renal disease. Scientific advances led to the development of an artificial kidney for clinical use in the 1940s and successful kidney transplantation in the 1950s, inaugurating a new era in organ transplantation. The new specialty of nephrology was born and developed in the 1960s; [1,2] in Cuba, it began in 1962, two years after the First International Congress of Nephrology.[1]

The first known attempted cadaveric-donor kidney transplantation in a human was by Yuri Yurievich Voronov, a Ukrainian physician, in 1933. However, it was not until the 1950s that several successful outcomes were obtained (1952, the first with a living relateddonor-mother to child-by Hamburger in Paris; 1954, the first in identical twin brothers, by Merrill and Murray in Boston).[3] Early attempts in Latin America-generally unsuccessful-began in the late 1950s. Pioneers were Argentina (1956-57), Mexico (1963), Brazil (1964), Colombia and Peru (1965), Venezuela (1967), Puerto Rico (1968), Costa Rica, Uruguay (1969) and Cuba.[4]

In Cuba, three different surgical teams each performed a kidney transplantation in 1968 and 1969. They grafted kidneys from cadaveric donors with cardiac arrest-matched solely on blood group compatibility-into three young male patients, two with end-stage renal disease of unknown etiology and one whose only kidney had to be removed because of uncontrollable traumatic hematuria.

Following consent from their families, kidney transplantations were done as a last attempt to save the patients' lives, despite risks involved and paucity of related resources, experience and scientific knowledge at the time.[5] None of the transplants was successful, the patients dying within a few days postoperatively, among other reasons from lack of a program for repeated dialysis.[5] formed 893 grafts during this period. HLA-DR typing was introduced in 1976 and the National Histocompatibility Laboratory Network was founded in 1978. The first related living-donor kidney transplantation was done in 1979. 1986-2011: The National Kidney Transplantation Coordinating Center and the National Kidney Transplantation Program were created in 1986; the first combined kidney-pancreas transplantation was performed the same year. In 1990, cyclosporine and the Cuban monoclonal antibody IOR-T3 were introduced for immunosuppression to prevent rejection, as were other Cuban products (hepatitis B vaccine and recombinant human erythropoietin) for transplant patients. By December 2011, the cumulative number of transplants was 4636 (384 from related living donors). With over 40 years of experience, kidney transplantation is now well established in Cuba; it is free and universally accessible, on the basis of need and appropriateness.

KEYWORDS Kidney transplantation, grafting/kidney, end-stage kidney disease, end-stage renal disease, renal insufficiency, living donors, organ donors, organ transplants, history of medicine, nephrology, Cuba

The objective of this paper is to describe the history of kidney transplantation in Cuba, looking at its background, beginnings, development, evolution and outcomes.

\section{METHODS}

A review was done of all national and international medical publications by Cuban and international authors on the subject of kidney transplantation in Cuba, reports from the National Kidney Transplantation Coordinating Center, and personal accounts from key informants who participated in this activity since its beginning.

Collected information was organized for description and analysis into four periods characterizing development of kidney transplantation in Cuba:

- 1962-1969, historical background, birth of nephrology and laying of groundwork to enable kidney transplants.

- 1970-1975, first successful kidney transplants, development of histocompatibility laboratories and national nephrology services; first steps in kidney exchange, nephrology services and human resource training).

- 1976-1985, creation of a national kidney transplantation program and network using cardiac arrest, brain-dead and living first-degree related donors, and opening of the National Kidney Transplantation Coordinating Center in the recently established national Dr Abelardo Buch López Nephrology Institute (INEF, the Spanish acronym).

- 1986-2011, consolidation of national kidney and kidneypancreas transplantation program, with five regions covering Cuba's 47 nephrology services and five histocompatibility laboratories. 
EVOLUTION OF RENAL TRANSPLANTATION SERVICES

Background (1962-1969) In the second half of 1962, the Ministry of Public Health selected three internists at the Joaquín Albarrán Provincial Clinical-Surgical Teaching Hospital in Havana to work on an artificial kidney installed at the hospital, under the guidance of a nephrologist from the nephrology section of the Prague Institute of Cardiology.

These specialists, once trained, formed the first dialysis unit in Cuba (making their hospital the birthplace of Cuban nephrology), which provided hemodialysis and peritoneal dialysis to patients with acute kidney failure. Four years later, in 1966, INEF was established in the same hospital, by virtue of Resolution 500/66 of the Minister of Public Health.[5]

In late 1967 and early 1968, INEF's director and deputy director visited the main European nephrology centers (in France, Czechoslovakia, Bulgaria and England). In 1969, another nephrologist in the transplantation working group was sent to Paris for a year of practical training in transplantation at Necker-Enfants Malades Hospital, one of the world's most experienced kidney transplantation centers at the time.

During these years (1962-1969), only patients with acute kidney failure received dialysis. In 1969, Cuba acquired the first two British-manufactured Lucas artificial kidneys, which used continuous flow dialysate; these, along with intermittent peritoneal dialysis, allowed extension of treatment to patients with chronic kidney failure. This plan was formalized in late 1969 and early 1970, in preparation for initiating kidney transplants from cadaveric cardiac-arrest donors.[5]

By early 1970 , conditions had been created to begin kidney transplants: patients who needed them; a program of repeated support dialysis; surgical and clinical medical personnel with teaching status and experienced in treatment of patients with all types of kidney failure; current information on transplantation; availability of immunosuppressive drugs in use at that time (azathioprine and prednisone); and the backing of the university teaching hospital adjacent to INEF. Thus, in January 1970, the Ministry of Public Health authorized INEF to begin kidney transplantation with cadaveric cardiac-arrest donors.

Birth and early development (1970-1975) The decisive year in Cuba was 1970, which marked the beginning of kidney transplantation.[5-7] The same month that transplantation was approved, the kidney transplantation group began monitoring emergency services in the Havana Emergency Hospital (now Freyre de Andrade Clinical-Surgical Teaching Hospital), which was the city's main intake and treatment center for trauma patients, alert for potential donors among the recently deceased.

The first donor After several days, the first donor actually was found in the neurosurgery service of nearby Calixto García University General Hospital, where a neurosurgical team certified a patient's death. The deceased was a male aged 50 years in cardiac arrest who died from head trauma and whose blood type was A-positive.[5-7]

Once death from cardiac arrest was certified and with consent of the family, bilateral nephrectomy was carried out, and rushed on ice to INEF to be grafted into two recipients.
Initiation of the national kidney transplantation plan: first transplants The first three transplant recipients (TI-001, TI-002 and TI-003) were chosen solely on the basis of blood group compatibility from among a small number of patients in the INEF dialysis program, and transplantations were carried out at INEF. The first two were performed one after the other on the same day, February 7,1970 , using the two kidneys obtained from the first donor. Neither was successful. In the first instance, the kidney recovered function following 11 days of anuria, during which four dialysis sessions were required, decreasing serum creatinine to $2.58 \mathrm{mg} / \mathrm{dL}$. On day 25 , the patient developed a urinary fistula from an opening in the bladder and subsequent infection and rupture of the renal artery (caused by excessive vessel dissection), which led to graft nephrectomy. The patient resumed chronic dialysis and died one year later of septicemia. The second recipient developed postoperative respiratory failure (caused by Imbretyl, a relaxant metabolized by the kidney) from which he did not recover, dying a few hours later.

The third patient ( $\mathrm{Tl}-003)$ received a transplant on February 24, 1970; the kidney was from a cadaveric cardiac-arrest donor and there was no cross-matching or HLA compatibility testing. It was the first successful transplant in Cuba, with the patient enjoying useful and prolonged graft function, eventually dying 17 years later of alcoholic cirrhosis, still with normal kidney function.

The fourth transplant patient (TI-004), March 12, 1970, had characteristics similar to the first three, but the patient died on the second postoperative day from prolonged anoxia leading to brain death, due to a defect in the anesthesia machine.

On May 5, 1970, the fifth transplantation of the initial series was performed (on patient TI-005), with a kidney from a male cadaveric cardiac-arrest donor aged 33 years, and matched solely by blood group compatibility. The recipient maintained kidney function for 36 years and still had stable renal function when he died on January 29, 2006 of acute left ventricular failure. [8-11] This was one of two cadaveric-donor transplants in the first five years with graft survival of 36 years-still world records for post-transplantation survival—despite absence of cross-matching or HLA typing.[10]

In 1970, 17 kidney transplantations were performed on 16 recipients (a 15-year-old girl received two transplants). Four of these patients lived with functional kidneys for more than 15 years: TI-003, 17 years; TI-005, 36 years; TI-007, 24 years; and TI-012, 25 years. The group's 10-year graft survival (per Kaplan-Meier curve) was $23.5 \%$. All were from cadaveric donors (eight with cardiac arrest and nine with brain death) and matched by blood group; recipients received high doses of azathioprine and prednisone as immunosuppressive therapy, similar to that used in the first four cases.[12] The first transplantation from a brain-dead donor was done on July 20, 1970; the first retransplantation on December 16, 1970; and March 30, 1971 marked the first time a single patient received a third transplantation.[5]

A national epidemiological study was done of deaths in Cuba from chronic kidney failure (1972-1975), with autopsy confirmation in $89 \%$ of cases. The chronic kidney failure mortality rate observed was 118 per million population (pmp) overall nationally (rates by 
province ranged from 102 to $132 \mathrm{pmp}$ ), and $47 \mathrm{pmp}$ for persons aged 10 to 49 years, consistent with international rates used as a baseline for Cuba's kidney disease prevention, dialysis and transplantation programs.[13]

During this stage, kidney transplantation became well established and was expanded. By December 1975, 170 grafts had been done (the first 100 without cross-matching or HLA typing): 20 in the nephrology service of Havana's Luís Díaz Soto Central Military Hospital, 33 at the Saturnino Lora Interprovincial ClinicalSurgical Teaching Hospital in Santiago de Cuba, and 117 at INEF in Havana. Overall results were similar to those reported internationally, with mean 1 -year cadaveric-donor graft survival $>60 \%$. Thus, Cuba became established in this discipline in Latin America and the first Cuban papers on the subject were published. [6-9,11,12,14-19,21,24-27]

\section{Achievements:}

- Initiation of kidney transplantation in Cuba in a relatively short time, creating a solid foundation for a national program.

- Initiation of HLA typing for kidney transplantation donor-recipient matching (the first workshop in Cuba on histocompatibility studies was held in 1974 by Dr Jean Dausset, winner of the Nobel Prize in Physiology or Medicine for creating the technique).[22,24]

- Development of computer programs for automated donorrecipient matching, the first such clinical application in Cuba, and pioneers in Latin America for automated donor-recipient matching.[27,28]

- Initiation of cadaveric-donor kidney exchange among the three existing transplantation centers (1974).[5]

Growth and Evolution (1976-1985) The national network of nephrology services with transplantation capacity was completed, and by close of 1985 (Table 1), a cumulative total of 893 grafts had been performed in seven accredited centers. National histocompatibility workshops were held in the provinces of Santiago de Cuba, Camagüey and Villa Clara, with night courses on clinical immunology and transplantation, resulting in functioning histocompatibility laboratories in each of these provinces. From its beginning, the INEF immunology laboratory served as a national reference center for laboratories supporting kidney transplanta-

Table 1: Kidney transplants in Cuba, 1970-1985

\begin{tabular}{l|r}
\hline Facility (City) & \multicolumn{1}{|c}{$\begin{array}{c}\text { No. of } \\
\text { transplants }\end{array}$} \\
\hline Dr Abelardo Buch López Nephrology Institute (Havana) & 430 \\
\hline $\begin{array}{l}\text { Saturnino Lora Interprovincial Clinical-Surgical Teaching } \\
\text { Hospital (Santiago de Cuba) }\end{array}$ & 281 \\
\hline Manuel Ascunce Domenech Provincial & 81 \\
Clinical-Surgical Teaching Hospital (Camagüey) & 40 \\
\hline Hermanos Ameijeiras Clinical-Surgical Teaching Hospi- & 30 \\
tal (Havana) & 25 \\
\hline Luis Díaz Soto Central Military Hospital (Havana) & 6 \\
\hline $\begin{array}{l}\text { Arnaldo Milián Castro Clinical-Surgical Hospital (Santa } \\
\text { Clara) }\end{array}$ & 893 \\
\hline Medical-Surgical Research Center (CIMEQ) (Havana) & \\
\hline TOTAL & \\
\hline Source: National Kidney Transplantation Coordinating Center &
\end{tabular}

tion.[5] The National Histocompatibility Laboratory Network was formed in 1978.[24]

Transplantation law versus voluntary donation In the early 1980 s, there was discussion of the need for a law regulating donation and transplantation of organs and tissues, and whether there should be compulsory donation or reliance on heightened public humanitarian awareness. Cuba chose the second path: the public had become very sensitive to the need for a donationtransplantation process, and only about $13 \%$ of families refused consent for donation. In addition, Cuba has strict criteria for brain death that meet international standards and certification of brain death is confirmed by qualified personnel outside the kidney transplantation group, reviewed frequently by competent authorities and discussed at national and international scientific meetings. $[29,30]$

\section{Achievements:}

- Introduction of HLA-DR tissue typing (1976).[22]

- First kidney transplantation with living first-degree related and HLA-compatible donor (1979). However, over $90 \%$ of transplants involved deceased donors.[5]

- Consolidation of kidney transplantation in children. From February 1970 to December 1985, 893 cadaveric-donor kidney transplants were done in Cuba (430 grafts in the last 10 years). Of these, 49 patients were aged 9 to 16 years; $98 \%$ aged $>10$ years.[5]

- Initiation of multiple organ procurement for transplantation of different organs: heart, kidney, cornea, etc.[5]

Consolidation and Expansion (1986-2011) In this stage, the National Kidney Transplantation Program was consolidated and expanded, growing to nine transplantation centers distributed across the country-five in Havana and one each in Santa Clara, Camagüey, Holguín and Santiago de Cuba; five histocompatibility laboratories, and 33 hospitals authorized as organ procurement centers. The country was divided into five regions for kidney transplantation: the West (Isle of Youth Special Municipality and the provinces of Pinar del Río, Matanzas and what are now Havana, Artemisa and Mayabeque); Villa Clara (Villa Clara, Sancti Spíritus and Cienfuegos provinces); Camagüey (Camagüey and Ciego de Avila provinces); Northeast (Holguín, Granma and Las Tunas provinces); and Southeast (Santiago de Cuba and Guantánamo provinces) (Table 2, Figure 1).

In December 2011, 2714 patients were receiving renal replacement therapy (242 pmp): 2614 (96.4\%) on hemodialysis and 100 $(3.6 \%)$ on peritoneal dialysis. The cumulative total of functioning kidney transplants was 815 (76 pmp).

\section{Achievements:}

- Creation of the National Kidney Transplantation Program (1986), directed by INEF and comprising seven transplantation centers, five histocompatibility laboratories and a computerized donor-recipient selection/matching system.[31-33]

- First pediatric kidney transplant, performed at the Central Havana Pediatric Teaching Hospital on February 19, 1988. As 
Table 2: Cadaveric-donor kidney transplants by facility, Cuba (1970-2011)

\begin{tabular}{|c|c|c|c|c|c|}
\hline Facility (City) & \multicolumn{5}{|c|}{ No. of transplants } \\
\hline Saturnino Lora Interprovincial Clinical-Surgical Teaching Hospital (Santiago de Cuba) & 680 & 109 & 134 & 83 & 1006 \\
\hline Vladimir I. Lenin and Lucía Îniguez Landín Hospitals (Holguín) & 0 & 78 & 186 & 278 & 542 \\
\hline Manuel Ascunce Domenech Provincial Clinical-Surgical Teaching Hospital (Camagüey) & 236 & 69 & 117 & 75 & 497 \\
\hline Luis Díaz Soto Central Military Hospital (Havana) & 73 & 21 & 50 & 7 & 151 \\
\hline Central Havana Pediatric Teaching Hospital (Havana) & 37 & 13 & 10 & 17 & 77 \\
\hline TOTAL & 2259 & 579 & 993 & 799 & 4630 \\
\hline
\end{tabular}

Source: National Kidney Transplantation Coordinating Center

of December 2011, 83 kidney transplants had been performed at this hospital, eight with a living donor. [5] Pediatric kidney transplantation by the adult transplantation team continued at the Medical-Surgical Research Center (CIMEQ) in Havana in collaboration with the Central Havana Pediatric Teaching Hospital, together achieving 105 transplants, 23 with a living related-donor. Pediatric transplantation was also being performed in Santiago de Cuba, Villa Clara and Camagüey; and in Holguín since 2011.

- Creation of the National Kidney Transplantation Coordinating Center (1988) in INEF, with round-the-clock emergency personnel and telephone communication with all kidney dialysis and transplantation centers, surgical teams, histocompatibility laboratories and logistical agencies; as well as a database of eligible kidney transplant recipients and an upgraded computerized donor-recipient selection system.[5]

- First combined kidney-pancreas transplant, January 31, 1986, by a multidisciplinary team from the Nephrology and Endocrinology Institutes, in collaboration with the General Calixto García University General Hospital and Joaquín Albarrán Provincial Clinical-Surgical Hospital; the patient was a male aged 48 years from Pinar del Río province. Twenty-one such transplants were done, with survival $>3$ years. The program was suspended in 1992 due to the economic crisis in the 1990s known as the Special Period.[34-38]

- Increase in number of kidney transplants per year, reaching 237 in 1992, which translates to 22 transplants pmp (the highest rate in the history of kidney transplantation in Cuba), one of the best rates in Latin America, where the average that year was 5.9 pmp.[37-39]

- Initiation of use of cyclosporine and IOR-T3, a Cuban-manufactured monoclonal antibody, for prophylactic immunosuppression (November 1989)[40,41] and for acute kidney transplant rejection.[42,43] Beginning of use of Cuban hepa- titis B vaccine[44] in all dialysis patients and dialysis units' personnel.

- Introduction and widespread use of domestically produced recombinant human erythropoietin.[45,46]

\section{CHALLENGES AND PROSPECTS}

There are many challenges: improve proper functioning of the recipient waiting list; expand the number of patients eligible to receive transplants and reduce waiting times;

- modernize the computerized donor-recipient selection system by introducing new algorithms and priorities;

- increase percentage of kidneys extracted and decrease unused ones;

- improve donor-recipient HLA system compatibility (the majority of transplants are done with a high percentage of incompatibilities) and place greater emphasis on patient selection by percentage of sensitization;

- increase the number of transplants above the $22 \mathrm{pmp}$ reached in 1992;

- continue reducing the marked differences among services in survival percentages for deceased-donor kidney transplanta- 
tion (best results for 2010 were in Lucía Iñiguez Landín Clínical-Surgical Hospital in Holguín, 80\%; Arnaldo Milián Castro Clinical-Surgical Hospital in Villa Clara, 85\%; and Hermanos Ameijeiras Clinical-Surgical Teaching Hospital in Havana, $75 \%$, with a national average of $74.9 \%$ );

\section{- decrease surgical complications;}

- stabilize human resources devoted to this activity; and

- increase the proportion of living-donor transplants to $15 \%$.

Because of the technology required and its high cost, kidney transplantation is usually the prerogative of countries with ample resources and advanced scientific development. Starting kidney transplantation only a few years after its global debut, without prior experience and with extremely scarce resources, represented a great challenge for Cuban public health. Nevertheless, kidney and kidney-pancreas transplantation in Cuba have always been free of charge and accessible according to need and appropriateness. The early years involved arduous work by a small multidisciplinary group, which, because of successes in outcomes and the number of transplants-comparable to those obtained internationally - distinguished Cuban organ transplantation in the Latin American context.

Today Cuba has a strong kidney transplantation program; $90 \%$ of transplanted kidneys are from donors with certified brain death and $10 \%$ from living related donors (parents, offspring and siblings). Perhaps more challenging than beginning this program in the first place is to maintain and continue developing it as a system that fulfills the needs of Cuba's citizens and the quality standards that have distinguished it thus far, particularly amidst complex and challenging economic circumstances. - th-

\section{REFERENCES}

1. Richet G. International Society of Nephrology. A brief history of the International Society of Nephrology. Kidney Int. 1989 Nov;36(5):938-40.

2. Robinson R, Richet G. History of the International Society of Nephrology. Kidney Int. 2001;59(Suppl 79):S1-S100.

3. Hume DM, Merrill JP, Thorn G. Experiences with renal homotransplantations in human. Report of nine cases. J Clin Invest. 1955;34327-36.

4. Petruccelli D, Llopart T, Corio E, Turnes AL. Recuerdos de los comienzos de la Nefrología en Uruguay. Montevideo (UY): Ed. Tradinco S.A; 2009. Spanish.

5. Alfonzo JP. Historia del trasplante renal en Cuba. Havana: ECIMED. Spanish. Forthcoming 2012.

6. Busch A. Trasplante renal de riñón de cadáver en Cuba. Resumen del V Congreso Internacional de Nefrología. México DF: [publisher unknown]; 1972. Spanish.

7. Busch A, Magrans C, Ferrandíz R, Casals J, Mañalich $\mathrm{R}$, Suárez $\mathrm{O}$, et al. Nuestra experiencia en el trasplante renal. Reporte preliminar. Rev Cubana Cir. 1992 Sep-Dec;11:407-33. Spanish.

8. Gómez Sampera A. Trasplante renal. Aspectos quirúrgicos. Rev Cubana Cirug. 1971;10:559-72. Spanish.

9. Suárez $O$, Magrans $C$, Gómez A, Mañalich R, Rodríguez A, Fragoso A, et al. Estudio de 102 trasplantes renales. Aspectos quirúrgicos. Rev Cubana Cirug. 1975;14:153-64. Spanish.

10. Pérez A, Mármol A, Parodis $Y$, Molina S, Pérez de Prado JC, Herrera M. Trasplante renal en Cuba con más de 36 años de evolución. Rev Cubana Med. 2006;45(3). Spanish.

11. Rodríguez $P$, Sampera $A$, Suárez $O$, Rodríguez A, Magrans C, Mañalich R, et al. Estenosis de la arteria renal simulando crisis de rechazo en un paciente con trasplante renal. Rev Cubana Cir. 1973;12:443-9. Spanish.

12. Magrans C, Alfonzo JP, Mañalich R, Gómez A, Rodríguez A, Suárez $O$, et al. Trasplante renal. Experiencias en 36 trasplantes de más de un año de realizados. Rev Cubana Cir. 1974;13:421-6. Spanish.

13. Almaguer M. Estudio nacional de mortalidad por IRC [thesis]. [Havana]: National Institute of Nephrology (CU); 1975. Spanish.

14. Buch A, Magrans C, Heras A, Mañalich R, Alfonzo JP, González O, et al. Valor de la diálisis peritoneal en el trasplante renal. Rev Cubana Cirug. 1973;12:111-5. Spanish.

15. Gómez A, Rodríguez A, Magrans C, Mañalich $\mathrm{R}$, Alfonzo J. Nefrectomía bilateral: indicacio- nes, técnica y resultados. Rev Cubana Cir. 1973;12:243-52. Spanish.

16. Gómez A, Rodríguez A, Suárez $O$, Rodríguez $\mathrm{P}$, Magrans C, Alfonzo J, et al. Fístula piélica en trasplante renal simulando ascitis tratada quirúrgicamente con éxito. Rev Cubana Cir 1973;12:435-41. Spanish.

17. Alfonzo JP, Pita A, Magrans C, Mañalich R, González O, Heras A, et al. La arteriografía en el trasplante renal. Rev Cubana Cir. 1973;12:42533. Spanish.

18. Gómez A, Rodríguez A, Alfonzo J, Filgueira E. Complicaciones urológicas en los trasplantes renales. Rev Cubana Cirug. 1974;12:555-64. Spanish.

19. Magrans C, Alfonzo JP, Heras AS, Mañalich R, Gómez H. Las necrosis tubulares isquémicas agudas en el trasplante renal. Bol Nefrourológico. 1974;2(1):3-12. Spanish.

20. Alfonzo JP, Díaz J, Rodríguez O, Campos L, Blanco R. Hipertensión arterial en el trasplante de riñón de cadáver. La Habana. Estudio de 63 casos con supervivencia superior a 3 meses. Rev Cubana Cir. 1976;15:335-43. Spanish.

21. Suárez $O$, Magrans $C$, Gómez $A$, Mañalich $R$, Rodríguez A, Fragoso A, et al. La Habana. Estudio de 102 trasplantes renales. Aspectos quirúrgicos. Rev Cubana Cir. 1975;14:153-64. Spanish.

22. Arce S, Ballester JM, Alfonzo JP, Almaguer M. Tipaje tisular (HL-A) y su influencia en el mejoramiento de los resultados terapéuticos del trasplante renal, empleando un pequeño número de receptores. Rev Cubana Med. 1978;17:195-7. Spanish.

23. Mañalich R. Utilidad de la gammagrafía renal con un scanner rectilíneo en la valoración del riñón trasplantado. Rev Cubana Med. 1978;17:11-7. Spanish.

24. Arce S, Ballester JM, Álvarez L, Palacios C. Taller Internacional de Histocompatibilidad. Análisis de algunos resultados a la luz de la estadística y mediante el empleo de la computación electrónica. Bol Nefrourológico. 1975;2(3):138-48. Spanish.

25. Alfonzo Guerra JP, Rodríguez A, Gómez A, Mañalich R, Magrans C, Buch A. Anuria obstructiva en trasplante renal. Experiencia en 136 trasplantes. Bol Nefrourológico. 1975;1:50-9. Spanish.

26. Gómez A, Alfonzo JP, Rodríguez A, Suárez O, Rodríguez P. Fístulas urinarias en trasplantes renales de donante cadavérico. Rev Cubana Cir. 1975;14:166-72. Spanish.

27. Alfonzo JP, Rodríguez O. Aplicación de la computación en el trasplante renal. Rev Cubana Cir. 1974;13:565-73. Spanish.
28. Alfonzo JP. Programa de selección de receptores para trasplante renal mediante un programa de computación electrónica. Rev Cubana Med. 1978;17:199-206. Spanish.

29. Mármol A, Herrera R. Ética del trasplante, reflexiones en el campo de la Nefrología. Bioética. Havana: Editorial Félix Varela; 1997. p. 246-57. Spanish.

30. Buch A, Alfonzo JP. Plan de trasplante renal "Cuba-Trasplante". Primer informe anual basado en la metodología del intertrasplante del CAME. Rev Cubana Cir. 1980;19:273-83. Spanish.

31. Mármol A, Herrera R, Moreno D. Organ procurement and renal transplantation in Cuba, 1994. Transplant Proc. 1996 Dec;28(6):3356.

32. Mármol A, Pérez A, Pérez de Prado JC, Herrera R. Trasplante renal en Cuba. Rev Cubana Med [Internet]. 2005 [cited 2012 Jan 4];44(1-2). Available from: http://bvs.sld.cu/revistas/med/vol44 1-2_05/med10105.htm. Spanish.

33. Mármol A, Pérez A, Muñoz LC, Arce S. Renal transplantation program in Cuba. Transplant Proc. 2009 Oct;41(8):3505-6.

34. Sotolongo Y. Método anestesiológico del trasplante combinado páncreas-riñón. Nuestra experiencia. Rev Cubana Cir. 1988 SepOct;27(5):32-8. Spanish.

35. Bohorques R, Alfonzo JP. Tratamiento sustitutivo de las funciones del riñón en la insuficiencia renal crónica terminal por nefropatía diabética. Rev Cubana Med. 1988 Aug;27(8):5-13. Spanish

36. Mármol A, Pérez A, Pérez de Prado JC, Fernández S, Gutiérrez F, Arce S. Programa de trasplante renal en Cuba. Rev Cubana Med. 2009 Oct-Dec;48(4):238-43. Spanish.

37. Franco M, Orduñez P, Caballero B, Cooper RS. Obesity reduction and its possible consequences: What can we learn from Cuba's Special Period? CMAJ. 2008 Apr 8;178(8):1032-4.

38. Pérez-Oliva JF, Herrera R, Almaguer M, Pérez $M$, Mármol A. Current status of renal replacement treatment in Cuba. Nefrología. 2005;25(6):721-2.

39. Cusumano AM, Di Gioia C, Hermida O, Lavorato C; Latin American Registry of Dialysis and Renal Transplantation The Latin American Dialysis and Renal Transplantation Registry Annual Report 2002. Kidney Int Suppl. 2005 Aug;(97):S46-52.

40. Enamorado A. Ensayo terapéutico con anticuerpos monoclonales IOR t3 en un esquema cuádruplo de tratamiento en el trasplante renal [thesis]. [Havana]: National Institute of Nephrology (CU); 1990. Spanish. 
41. Herrera R, Enamorado A. Uso del IOR T-3 en la inducción del trasplante renal. Rev Española Traspl. 1994;3(1):44-52. Spanish.

42. Herrera R, Moreno D, Enamorado A, Cuéllar C, Alfonzo J, Mármol A. Profilaxis del rechazo en el trasplante renal con el anticuerpo monoclonal (AcM) iort3. Rev Española Traspl. 1994;13(1):44-9. Spanish.

43. Delgado A, Kokuina E, Marrero I. Uso del anticuerpo monoclonal ior $\mathrm{t} 3$ en el rechazo esteroide resistente. Rev Española Traspl. 1992;4(4):2937. Spanish.

44. González MJ, Cinza Z, Ortega A, Gali MM, Santoyo ME, García G, et al. Estudio comparativo entre diferentes esquemas de administración de 2 dosis con la vacuna cubana antihepatitis B. Rev Cubana Med Trop. 1998 Sep-Dec;50(3). Spanish.

45. Pérez-Oliva JF, Casanova-González M, García-García I, Porrero-Martín PJ, Valenzuela-Silva $\mathrm{CM}$, Hernández-Montero $\mathrm{T}$, et al. Comparison of two recombinant erythropoietin formulations in patients with anaemia due to end-stage renal disease on haemodialysis: a parallel, randomized, double blind study. BMC Nephrol. 2005 May 23;6:5-11.

46. Pérez Oliva JF, Lagarde AM, Herrera Valdés R, Martínez AI, Raola ME, Magrans C. Broad use of Cuban recombinant human erythropoietin (IOR-EPOCIM) in dialysis patients at the
Institute of Nephrology. MEDICC Rev. 2005 May;7(5):11-4.

\section{THE AUTHOR}

Jorge P. Alfonzo Guerra (jalfonzo@infomed. sld.cu), nephrologist. Full professor and consulting nephrologist, Nephrology Institute, Havana, Cuba.

Submitted: January 18, 2012

Approved for publication: January 7, 2013

Disclosures: None 